\title{
Anti-Interleukin-6 and Janus Kinase Inhibitors for Severe Neurologic Toxicity of Checkpoint Inhibitors
}

Alberto Picca, MD, Nefeli Valyraki, MD, Cristina Birzu, MD, Nora Kramkimel, MD, PhD, Olivier Hermine, MD, PhD, Noel Zahr, PharmD, PhD, Giulia Berzero, MD, PhD, * and Dimitri Psimaras, MD*

Neurol Neuroimmunol Neuroinflamm 2021;8:e1073. doi:10.1212/NXI.0000000000001073

\section{Abstract}

\section{Background and Objectives}

To describe the marked clinical and biological responses of a targeted treatment with anti-interleukin-6 (IL-6)-receptor antibody and Janus kinase (JAK) inhibitors in a patient with a severe, corticoresistant CNS toxicity of immune-checkpoint inhibitor (ICI) therapy.

\section{Methods}

A 58-year-old man was admitted for subacute paraparesis, urinary retention, and ascending paresthesia. He was under treatment with ipilimumab and nivolumab for metastatic melanoma. Spine MRI disclosed multiple T2-hyperintense, contrast-enhancing longitudinally extensive lesions. A diagnosis of ICI-related acute transverse myelitis was made.

\section{Results}

ICIs were immediately discontinued, and the patient received high-dose glucocorticoids plus 1 session of plasma exchange, but he did not improve. Based on the marked elevation of CSF IL-6 $(505 \mathrm{pg} / \mathrm{mL})$, a second-line targeted therapy with anti-IL-6-receptor tocilizumab $(8 \mathrm{mg} / \mathrm{kg} / \mathrm{mo}$ for 3 infusions) plus JAK inhibitor ruxolitinib $(50 \mathrm{mg} / \mathrm{d})$ was administered. Patient neurologic status started to improve shortly after, with corresponding radiologic resolution. At 9 months, the patient was able to walk independently, presenting only slight residual disability while remaining in oncologic partial response.

\section{Discussion}

Our case suggests that some patients with severe, corticoresistant CNS immune-related toxicities of ICIs may benefit from cytokine blockade. Cytokine measurement in serum and CSF might help in selecting patients for personalized treatment strategies.

\author{
Correspondence \\ Dr. Psimaras \\ dimitri.psimaras@aphp.fr
}


Neurologic immune-related adverse events (irAEs) of immune-checkpoint inhibitors (ICIs) are uncommon but often severe and potentially life-threatening. High-dose glucocorticoids may be insufficient, ${ }^{1}$ but optimal treatment in severe and refractory cases remains to be defined.

In this study, we report the case of a 58-year-old man who started combined treatment with ipilimumab and nivolumab for $B R A F$-wild-type metastatic melanoma. After the fourth ICI cycle, the patient presented with rapidly progressing paraparesis, urinary retention, and ascending paresthesia, which peaked in 10 days from onset. Neurologic examination showed severe flaccid paraparesis, a dorsal sensory level (T10) with impaired proprioception, and absent deep tendon reflexes. Spine MRI disclosed multiple T2 hyperintensities at C2, C3, C7-T2, T4-T7, and T8-conus levels with associated patchy contrast enhancement (Figure 1, B and C). CSF analysis displayed increased proteins $(2.57 \mathrm{~g} / \mathrm{L})$ and cell count $\left(112 / \mathrm{mm}^{3}\right)$ with no malignant cells. Screening for anti-aquaporin-4, anti-myelin oligodendrocyte glycoprotein, anti-glutamic acid decarboxylase, and onconeural antibodies (including anti-Hu, anti-Ri, anti-CV2, and antiamphiphysin) was negative. Cytokine assessment showed a marked elevation of interleukin-6 (IL-6) in the CSF (505 $\mathrm{pg} / \mathrm{mL}$, upper normal limit $4 \mathrm{pg} / \mathrm{mL}$ ) (Figure 1A). After excluding alternative infectious, vascular, and neoplastic causes, a diagnosis of ICI-related acute transverse myelitis was made.

Figure 1 Imaging, Treatment, CSF Monitoring, and Functional Outcome in a Patient With Severe ICI-Related Myelitis

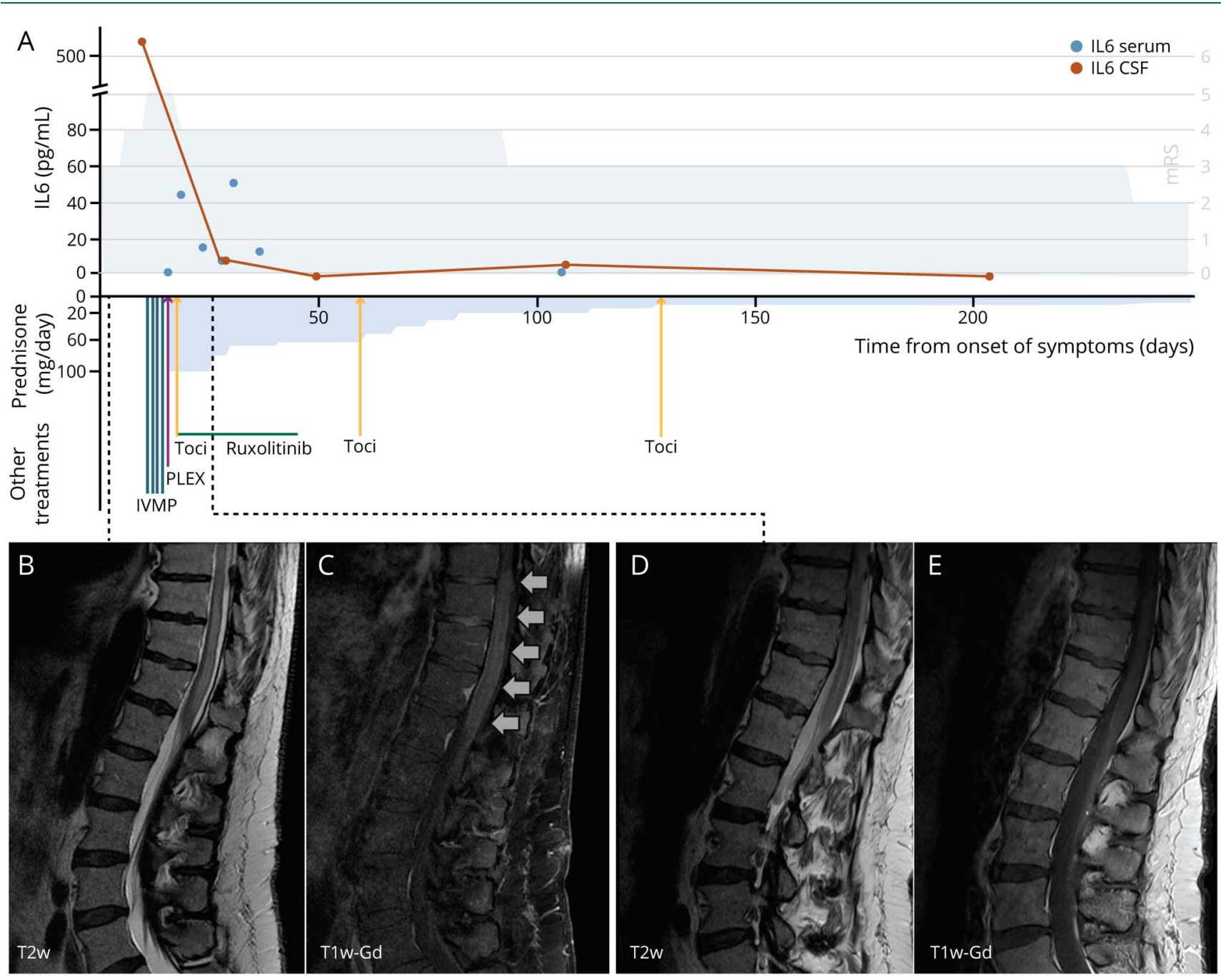

(A) Timeline of patient functional status (as expressed by the modified Rankin Scale [mRS], gray curve), IL-6 levels in CSF (orange dots) and serum (blue dots), and administered treatments. The first CSF analysis at day 10 from symptom onset displayed an inflammatory CSF with markedly increased IL-6 level (515 pg/ $\mathrm{mL}$ ) that rapidly decreased after the first administration of tocilizumab and introduction of oral ruxolitinib (8 pg/mL at day 29 and indetectable at day 50$)$. Follow-up CSF analysis at 3 months (day 107) disclosed a slight rise in CSF inflammatory markers (CSF IL-6: $6 \mathrm{pg} / \mathrm{mL}$; CSF proteins: $1.8 \mathrm{~g} / \mathrm{L}$; and CSF cells: 17/ $\mathrm{mm}^{3}$ ) that justified a third administration of IV tocilizumab despite the sustained clinical and radiological improvement. (B and C) Lumbosacral spine MRI at diagnosis displayed a longitudinally extensive lesion with spinal swelling from T8 to the conus in T2-weighted sequences (T2w) (B), with an associated faint parenchymal and leptomeningeal enhancement in postgadolinium T1-weighted images (T1w-Gd) (C). (D and E) Lumbosacral spine MRI 1 week after the introduction of tocilizumab and ruxolitinib, showing a marked reduction of the spinal hyperintensities in T2-weighted images (D) and resolution of the contrast enhancement in postgadolinium T1-weighted images (E). ICl = immune-checkpoint inhibitor; IL-6 = interleukin-6; IVMP = intravenous methylprednisolone; PLEX = plasma exchange; Toci $=$ tocilizumab. 
ICIs were immediately discontinued, and the patient received IV methylprednisolone ( $3.5 \mathrm{~g}$ over 4 days), followed by oral prednisone tapering (from $100 \mathrm{mg} / \mathrm{d}$ ) and 1 session of plasma exchange to remove residual circulating ICIs, but the patient did not improve. Based on our recent experience of poor responses to high-dose glucocorticoids and plasma exchanges in ICI-related myelitis ${ }^{1}$ and on the marked IL-6 elevation in the CSF, a second-line treatment with the anti-IL-6-receptor tocilizumab $(8 \mathrm{mg} / \mathrm{kg}$ IV every 4 weeks) was started, 14 days after symptom onset. To broaden the inhibition of cytokine signaling, the Janus kinase (JAK) inhibitor ruxolitinib (25 mg orally, twice daily) was initiated (Figure 1A). JAKs are crucial enzymes in downstream signaling of type I and type II cytokine receptors including IL-6R, being required for the activation of mitogen-activated protein kinase, phosphatidylinositol-4,5-bisphosphate-3-kinase, and signal transducer and activator of transcription pathways. Ruxolitinib was also added to prevent a possible initial worsening of inflammation due to the expected transient tocilizumab-induced elevation of IL- 6 and consequent signal transduction activation. ${ }^{2}$

Five days after starting second-line treatment, the patient started improving (Video 1), showing a parallel radiologic amelioration (Figure 1, D and E), a resolution of CSF inflammation, and a dramatic decrease of CSF IL-6 levels (Figure 1A). Measurement of drug levels, 2 weeks after starting second-line treatment, confirmed that both compounds were present in the CSF at therapeutic concentrations (tocilizumab: serum $21 \mu \mathrm{g} / \mathrm{mL}, \mathrm{CSF} 6 \mu \mathrm{g} / \mathrm{mL}$ and ruxolitinib: serum $138 \mathrm{ng} / \mathrm{mL}$, CSF $12.6 \mathrm{ng} / \mathrm{mL}$ ). At that time, protein levels in the CSF were $0.55 \mathrm{~g} / \mathrm{dL}$, reflecting a very mild bloodbrain barrier damage. Tocilizumab was continued for a total of 3 infusions, until a steady decrease of IL- 6 in the CSF was observed, whereas ruxolitinib was discontinued after 3 weeks because of grade 3 anemia.

At 3 months from myelitis onset, the patient was able to walk with support (Video 2) and constantly improve with physical therapy. At the last follow-up, 9 months from onset, he could walk independently without limitations of the walking perimeter (Video 3), and he was able to resume his work, although he still had mild sensory ataxia and a bladder and bowel dysfunction. Spinal MRI showed a substantial regression of previously reported abnormalities. Oncologic re-evaluation showed persistent partial response with no progression of his metastatic melanoma, and he remained on simple surveillance.

The present case, recently included in a series of longitudinally extensive myelitis, ${ }^{1}$ underscores the value of personalized treatment approaches in severe neurologic irAEs, as recently proposed for other irAEs. ${ }^{3,4}$ In this case, the marked increase of CSF IL- 6 suggested the potential value of IL-6receptor inhibition. Tocilizumab has recently demonstrated its efficacy in patients with ICI-related cerebritis ${ }^{5}$ and other non-ICI-related CNS inflammatory conditions, such as neuromyelitis optica spectrum disorder (NMOSD). ${ }^{6}$ Similarly, ruxolitinib was also effective in a patient with severe NMOSD. ${ }^{7}$ In this study, we demonstrated that both agents reach therapeutic concentrations in the CNS and might be effectively used to treat severe, corticoresistant neurologic irAEs. Nevertheless, we acknowledge the limitations of singlecase reporting; we cannot exclude that glucocorticoids and plasma exchange, or a naturally improving course of the disease itself, could have played a role in clinical and biological improvement. Our report is hypothesis generating, and further studies are needed. Cytokine measurement in serum and CSF might help to select patients that would benefit from cytokine blockade.

\section{Data Availability}

Further anonymized data will be made available upon reasonable request.

\section{Study Funding}

The authors report no targeted funding.

\section{Disclosure}

The authors report no disclosures relevant to the manuscript. Go to Neurology.org/NN for full disclosures.

\section{Publication History}

Received by Neurology: Neuroimmunology \& Neuroinflammation February 28, 2021. Accepted in final form June 15, 2021.

Appendix Authors

\begin{tabular}{lll}
\hline Name & Location & Contribution \\
\hline $\begin{array}{l}\text { Alberto } \\
\text { Picca, MD }\end{array}$ & $\begin{array}{l}\text { AP-HP, GH Pitié-Salpêtrière, } \\
\text { Service de Neurologie 2- } \\
\text { Mazarin, Paris, France }\end{array}$ & $\begin{array}{l}\text { Drafting/revision of the } \\
\text { article for content, including } \\
\text { medical writing for content; } \\
\text { major role in the acquisition } \\
\text { of data; study concept or } \\
\text { design; and analysis or } \\
\text { interpretation of data }\end{array}$ \\
$\begin{array}{lll}\text { Nefeli } \\
\text { Valyraki, }\end{array}$ & AP-HP, GH Pitié-Salpêtrière, & $\begin{array}{l}\text { Drafting/revision of the } \\
\text { article for content, including } \\
\text { MD }\end{array}$ \\
Mazarin, Paris, France & $\begin{array}{l}\text { medical writing for content; } \\
\text { major role in the acquisition } \\
\text { of data; and analysis or } \\
\text { interpretation of data }\end{array}$ \\
\hline
\end{tabular}

\begin{tabular}{lll}
\hline Cristina & AP-HP, GH Pitié-Salpêtrière, & Drafting/revision of the \\
Birzu, MD & Service de Neurologie 2- & $\begin{array}{l}\text { article for content, including } \\
\text { medical writing for content, } \\
\text { Mazarin, Paris, France }\end{array}$ \\
& & $\begin{array}{l}\text { and analysis or } \\
\text { interpretation of data }\end{array}$ \\
\hline
\end{tabular}

\begin{tabular}{lll}
\hline $\begin{array}{l}\text { Nora } \\
\text { Kramkimel, } \\
\text { MD, PhD }\end{array}$ & $\begin{array}{l}\text { AP-HP, Hôpital Cochin, } \\
\text { Department of Dermatology, } \\
\text { Paris, France }\end{array}$ & $\begin{array}{l}\text { Drafting/revision of the } \\
\text { article for content, including } \\
\text { medical writing for content; } \\
\text { major role in the acquisition } \\
\text { of data; and analysis or } \\
\text { interpretation of data }\end{array}$ \\
\hline $\begin{array}{l}\text { Olivier } \\
\text { Hermine, } \\
\text { MD, PhD }\end{array}$ & $\begin{array}{l}\text { AP-HP, Hôpital Necker, } \\
\text { Department of Haematology, } \\
\text { Imagine Institute, INSERM } \\
\text { France }\end{array}$ & $\begin{array}{l}\text { Drafting/revision of } \\
\text { the article for content, } \\
\text { including medical } \\
\text { writing for content, } \\
\text { and analysis or } \\
\text { interpretation } \\
\text { of data }\end{array}$ \\
& & \\
\hline
\end{tabular}


Appendix (continued)

\begin{tabular}{|c|c|c|}
\hline Name & Location & Contribution \\
\hline $\begin{array}{l}\text { Noel Zahr, } \\
\text { PharmD, } \\
\text { PhD }\end{array}$ & $\begin{array}{l}\text { AP-HP, GH Pitié-Salpêtrière, } \\
\text { Department of } \\
\text { Pharmacology, Paris, France }\end{array}$ & $\begin{array}{l}\text { Drafting/revision of } \\
\text { the article for content, } \\
\text { including medical } \\
\text { writing for content; } \\
\text { major role in the } \\
\text { acquisition of data; } \\
\text { and analysis or } \\
\text { interpretation } \\
\text { of data }\end{array}$ \\
\hline $\begin{array}{l}\text { Giulia } \\
\text { Berzero, } \\
\text { MD, PhD }\end{array}$ & $\begin{array}{l}\text { AP-HP, GH Pitié-Salpêtrière, } \\
\text { Service de Neurologie 2- } \\
\text { Mazarin, Paris, France; } \\
\text { Neurology Unit, IRCCS San } \\
\text { Raffaele Scientific Institute, } \\
\text { Milan, Italy }\end{array}$ & $\begin{array}{l}\text { Drafting/revision of } \\
\text { the article for content, } \\
\text { including medical } \\
\text { writing for content; } \\
\text { study concept or } \\
\text { design; and analysis } \\
\text { or interpretation } \\
\text { of data }\end{array}$ \\
\hline $\begin{array}{l}\text { Dimitri } \\
\text { Psimaras, } \\
\text { MD }\end{array}$ & $\begin{array}{l}\text { AP-HP, GH Pitié-Salpêtrière, } \\
\text { Service de Neurologie 2- } \\
\text { Mazarin, Paris, France; } \\
\text { OncoNeuroTox Group, Center } \\
\text { for Patients with Neurological } \\
\text { Complications of Oncologic } \\
\text { Treatments, GH Pitié-Salpetrière } \\
\text { et Hôpital Percy, Paris, France }\end{array}$ & $\begin{array}{l}\text { Drafting/revision of the } \\
\text { article for content, including } \\
\text { medical writing for content; } \\
\text { major role in the acquisition } \\
\text { of data; study concept or } \\
\text { design; and analysis or } \\
\text { interpretation of data }\end{array}$ \\
\hline
\end{tabular}

\section{References}

1. Picca A, Berzero G, Bihan K, et al. Longitudinally extensive myelitis associated with immune checkpoint inhibitors. Neurol Neuroimmunol Neuroinflamm. 2021;8(3): e967.

2. Teachey DT, Lacey SF, Shaw PA, et al. Identification of predictive biomarkers for cytokine release syndrome after chimeric antigen receptor T-cell therapy for acute lymphoblastic leukemia. Cancer Discov. 2016;6(6):664-679.

3. Martins F, Sykiotis GP, Maillard M, et al. New therapeutic perspectives to manage refractory immune checkpoint-related toxicities. Lancet Oncol. 2019;20(1): e54-e64.

4. Esfahani K, Elkrief A, Calabrese C, et al. Moving towards personalized treatments of immune-related adverse events. Nat Rev Clin Oncol. 2020;17(8):504-515.

5. Stroud CR, Hegde A, Cherry C, et al. Tocilizumab for the management of immune mediated adverse events secondary to PD-1 blockade. J Oncol Pharm Pract. 2019; 25(3):551-557.

6. Zhang C, Zhang M, Qiu W, et al. Safety and efficacy of tocilizumab versus azathioprine in highly relapsing neuromyelitis optica spectrum disorder (TANGO): an open-label, multicentre, randomised, phase 2 trial. Lancet Neurol. 2020;19(5) 391-401.

7. Hodecker SC, Stellmann JP, Rosenkranz SC, et al. Ruxolitinib treatment in a patient with neuromyelitis optica: a case report. Neurol Neuroimmunol Neuroinflamm. 2017; 4(2):e328. 


\title{
Neurology ${ }^{\oplus}$ \\ Neuroimmunology \& Neuroinflammation
}

\author{
Anti-Interleukin-6 and Janus Kinase Inhibitors for Severe Neurologic Toxicity of \\ Checkpoint Inhibitors \\ Alberto Picca, Nefeli Valyraki, Cristina Birzu, et al. \\ Neurol Neuroimmunol Neuroinflamm 2021;8; \\ DOI 10.1212/NXI.0000000000001073
}

This information is current as of September 8, 2021

Neurol Neuroimmunol Neuroinflamm is an official journal of the American Academy of Neurology.

Published since April 2014, it is an open-access, online-only, continuous publication journal. Copyright

Copyright $\odot 2021$ The Author(s). Published by Wolters Kluwer Health, Inc. on behalf of the American

Academy of Neurology.. All rights reserved. Online ISSN: 2332-7812.

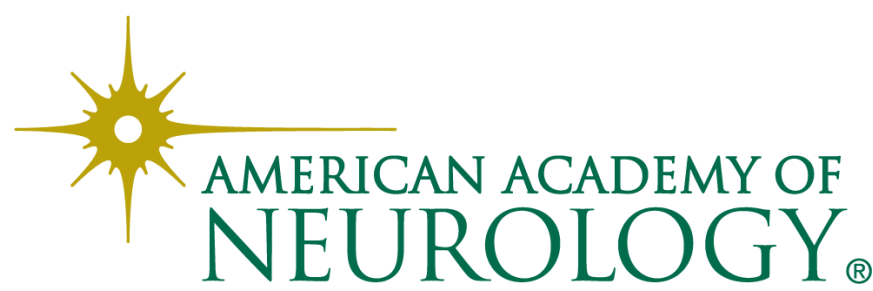




\section{Updated Information \& Services}

References

Citations

Subspecialty Collections

Permissions \& Licensing

Reprints including high resolution figures, can be found at: http://nn.neurology.org/content/8/6/e1073.full.html

This article cites 7 articles, 3 of which you can access for free at: http://nn.neurology.org/content/8/6/e1073.full.html\#\#ref-list-1

This article has been cited by 1 HighWire-hosted articles: http://nn.neurology.org/content/8/6/e1073.full.html\#\#otherarticles

This article, along with others on similar topics, appears in the following collection(s):

All Immunology

http://nn.neurology.org//cgi/collection/all_immunology All Oncology

http://nn.neurology.org//cgi/collection/all_oncology

Autoimmune diseases

http://nn.neurology.org//cgi/collection/autoimmune_diseases

Cerebrospinal Fluid

http://nn.neurology.org//cgi/collection/cerebrospinal_fluid

Transverse myelitis

http://nn.neurology.org//cgi/collection/transverse_myelitis

Information about reproducing this article in parts (figures,tables) or in its entirety can be found online at:

http://nn.neurology.org/misc/about.xhtml\#permissions

Information about ordering reprints can be found online:

http://nn.neurology.org/misc/addir.xhtml\#reprintsus

Neurol Neuroimmunol Neuroinflamm is an official journal of the American Academy of Neurology.

Published since April 2014, it is an open-access, online-only, continuous publication journal. Copyright

Copyright $\odot 2021$ The Author(s). Published by Wolters Kluwer Health, Inc. on behalf of the American

Academy of Neurology.. All rights reserved. Online ISSN: 2332-7812.

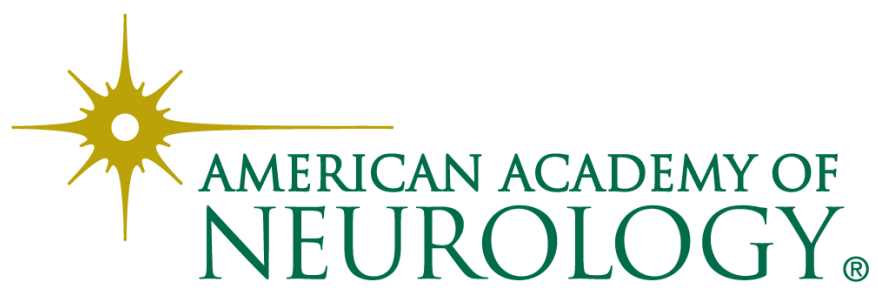

